\title{
KNOWLEDGE, SKILLS, AND ATTITUDES OF MALAYSIAN STUDENT ON GLOBAL CITIZENSHIP EDUCATION
}

\author{
Hamidah Yusof*, Mohd Asri Mohd Noor, Mahaliza Mansor, Jamal Yunus \\ Universiti Pendidikan Sultan Idris, Malaysia \\ *e-mail: hamidah.yusof@fpe.upsi.edu.my
}

\begin{abstract}
Student's perception on the current global citizenship education might have evolved. This study aims to identify the level of knowledge, skills, and attitudes of global citizenship from students' perceptions. It also examined the relationship between students' knowledge with the skills and attitudes of global citizenship. This study involved 155 first semester students in a public university in Malaysia. The selection of these respondents is to get their views on the education of global citizenship they received at schools. They were chosen because they had just finished secondary schools, and their experiences were still fresh in memory. They also came from various schools in Malaysia and able to draw on the experience of global citizenship education in Malaysia. This study was quantitative and used a questionnaire as the research instrument. The findings show that the level of knowledge, skills, and attitudes of students towards global citizenship is at a moderate level. The relationship between knowledge, skill, and attitude towards global citizenship is high, positive, and significant. The multiple linear regression analysis showed that skill and attitude are the predictors for the knowledge in the students. This study implies that global citizenship education is important to equip students to understand global issues and become global citizens.
\end{abstract}

Keywords: knowledge, skills, attitude, global citizenship education, students

\section{INTRODUCTION}

Global citizenship referred to the feelings of belonging to a specific community and shared the same perspectives of humanity. It consisted of political, economic, social and cultural interdependence and interconnectedness between the local, the national, and the global (UNESCO, 2015). This interconnectedness brings new transnational concepts to understand world issues and problems. Although the definition of global citizenship has not clearly defined, it has gained more popularity and effects on the community. One of the impacts is the need for "globalization learning" (Cheng, 2003). Friedman (2000) stated that globalization had affected every person and place in the world today. It moves from local to global and from nation to international - globalization in economic viewed as the increased power of organizations, human resources and global markets. Cheng (2003) stated that globalization implies the transfer, adaptation, and development of value, knowledge, technology, and norms of behaviour between nations and communities in the world.

The increasing awareness in this global citizenship resulted in increased attention given to the global dimension in citizenship education and its' implication to the policy, curricula, teaching and learning. Global citizenship education (GCE) widely discussed nowadays because of its impact on globalization (Rapoport, 2010; Davies \& Pike, 2011). Oxfam (2015) stated that global citizenship education is a framework that can be used to educate learners to engage critically and actively with the challenges and opportunities in life through a fast and interdependent world. It is transformative, developing the knowledge and understanding, skills, values, and attitude that learners need both to participate fully in a globalized society and economy and to secure a more just, secure and sustainable world than one they have inherited. The existing education system should be able to respond to the current trends and challenges of globalization. Wintersteiner, Grobbauer, Diendorfer \& Reitmair-Juárez (2015) stated that Global Citizenship Education is not just a theoretical concept but also a practical program that can be implemented at schools, in youth work and adult education.

The United Nations (UN) and its agency UNESCO had led the support and promotion of GCE at an early stage. UNESCO visioning GCE as an education that has holistic aspects 
in learning, acknowledging school must move 'beyond the development of knowledge and cognitive skills to build values, soft skills and attitudes among learners that can facilitate international cooperation and promote social transformation' (UNESCO, 2014). Therefore, UNESCO (2015) developed a specific learning module with clear guidelines in the content, topics and learning objectives that can be used to teach GCE in schools and other educational institutions. Through this learning guide, human rights education, peace education, sustainable education and civics and citizenship education clearly related to global citizenship education. Thus, the perceptions of students on global citizenship education in this study will refer to UNESCO's (2014) global citizenship education framework as a guideline in and Oxfam (2015).

This paper focused on the concept of global citizenship developed by UNESCO (2015), which divided education into three main areas, which are cognitive, sociocultural and behaviour. These dimensions serve as a base to define global citizenship education goals, its' learning objectives, competencies, and also for assessing and evaluating learning. A dimension of cognitive knowledge defined as a way to learn new knowledge; thinking critically and understanding at the global level, regional, national dan local; and connectivity and interconnectedness to different countries and its' population (UNESCO, 2015). This dimension adapted into Piaget's cognitive theory that emphasizes the development of the thinking process. Therefore, a cognitive or knowledge of GCE should be well communicated by teachers to build students understanding in solving problems and analyze issues. The second aspect is socioemotional or skills (UNESCO, 2015). This dimension defined as having the same sense of belonging and humanity, shared values and responsibilities, empathy, unity and respect for diversity.

This dimension has been adapted into Erickson's Psychosocial Theory. This theory states that a person's stage of life from birth shaped by the social influence that interacts physically or psychologically. This psychosocial development is also associated with feelings, emotions, personality, and changes in how individuals are related to each other. This theory is essential in shaping people skills who have a sense of responsibility towards global citizenship education as a whole. The third aspect is behaviour or attitude (UNESCO, 2015). This dimension defined as an effective and responsible action at national and global levels to make the world more peaceful and sustainable. This dimension adapted into the theory of Behaviourism (Pavlov, 1897). This theory affirms the importance of one's behaviour towards a given stimulus. Through this study, students' attitudes could be seen after they get a stimulus in terms of knowledge about global citizenship education and how they practice it in life.

The global citizenship education learning outcomes will describe the knowledge, skills, values and attitude that students will acquire and show from the teaching and learning of this education based on these three domains. Therefore, these knowledge, skills, and attitudes towards global citizenship should be applied to every educational level at school. According to UNESCO (2015), the main objective of Global Citizenship Education is to enable students to form an understanding of the worldwide structure, rights and responsibilities, global issues and the relationship between local and national processes and systems; to recognize and value differences and diverse identities in cultures, languages, religion, gender, humanity and skills; to develop and apply critical skills for civic literacy in critical inquiry, information technologies, media literacy, critical thinking, decision making, problemsolving, consultation, security building, social and personal responsibility; to recognize and identify values and beliefs that affect social and political decision making, perceptions of social justice and civic engagement; to build a sense of empathy and love for other people, environment and respect the diversity; to form values of social justice and judging critical inequalities of skills based on gender, socio-economic status, cultures, religion, age, and other issues; to participate and contribute to the latest global issues at the local, national and global levels as an responsive and responsible global citizen. Referring to the UNESCO report (2015), the development of global citizenship education has increased the world's attention to the importance of civic education and its implications in teaching and learning, curriculum and politics. The United Nations (UN) stated that global civic education provided understanding, skills, and values 
required by students to work together to address the global challenges in the 21 st century. These challenges include climate change, poverty, hunger and equity issues, and sustainability.

There is no specific design for the indicators, and no standard definition agreed worldwide on the description or definition of global citizenship education (UNESCO, 2014; UIS, 2014). NGOs (Oxfam, 1997), educators (Hunt, 2012) and academicians (De Andreotti, 2006) have developed various understanding and terms. Although the main domains of this education are generally found across all countries, there are still some differences found. These differences may be due to the different cultures in various countries. In Asia, global education is less focus on individual rights and more emphasis on 'moral development' and individual-societal relationship (Toh, Shaw \& Padilla, 2017). Therefore, in this study we have drawn the global citizenship education elements based on the theories given by Oxfam (2012) and UNESCO's (2015) namely 'human right', 'sustainable development', 'climate change', 'peace and non-violence', 'global citizenship', 'gender equality' and 'health and well-being'. These elements were measured based on knowledge, skill and attitude of the student's perceptions towards global education.

Kalidjernih (Zuriah, 2012) states that citizenship is multidimensional and often identified as a legal status of a person that allows them to live and act on certain boundaries with several indicators. Firstly, as a legal status that has implications on the position of citizens as human beings that working in law and having the right for legal protection. Secondly, as political agents who will have implications on the duty and right of participating in various public political institutions. Thirdly are the skills of citizens in a political society that provides a definite source of identity. Citizenship education recognized as an effective means in the process of establishing good citizens. Through this education, students will realize their rights and obligations at the state level, nation and communication with other countries. Stevens (2013, p.11): "Once a learner is provided with a globalized education, he or she has the tools and resources to be a global-minded learner. Thus, they will become a globally prepared, competent graduate to face the competition in a global economy".
Ferreira (2011) stated that the GCE's main concern is to create global awareness in society. However, her study found that research on global education, global citizenship and global workforce that focussed on high school students still scarce at that time. The study of the globalization phenomenon is still new and limited. A systematic review of empirical research by Goren \& Yemini (2017) found that only two studies (Hull \& Stornaiuolo, 2014; Niens, O'Connor, \& Smith, 2013) that focussed on students' perceptions and understanding regarding global citizenship and GCE. They stated that student-centred study is the most complex due to the wide variety of schools, programs, ages and populations. Therefore, teachers are having problems in educating and providing accurate information to the students. According to Park (Cho, 2016), GCE is a shift of paradigm from national-based identity education to the education that fosters a spirit of belonging in a global context. This globalization issue and challenges required worldwide awareness and action. Hence, emphasis on the awareness of issues such as poverty, war, climate change, political sustainability and stability are among the challenges that required the attention of every world community. Moreover, the knowledge and challenges arise from this issue could be applied in education. It will help to develop a sense of responsibility in resolving global issues and the awareness of sustainable development in every community (Cho, 2017). A recent study by UNESCO (2017a), the efforts to measure global citizenship education focussing on knowledge, skills and attitude to help young people to be global citizens.

There are many studies on global citizenship education that have been carried out locally or internationally to nourish the knowledge and role of the younger generation in global issues. However, Park \& Cho argued that the majority of these studies only focus on analyzing curriculum or specific programs (Bitna, 2017). There is limited research that explores the implementation of GCE (Park \& Cho, in Bitna, 2017) and a unified measurement for civic and global citizenship education (Thier, 2016; Ferreira, 2011; Skirbekk, Potančoková, \& Stonawski, 2013). Morais \& Ogden (2011) stated that although there are some excellent scales currently being used in education abroad, these scales are mostly focussed on the scope and did not align with the operational 
definition of global citizenship that emerges from the literature. Therefore, the used of elements 4.7 in this study as a measurement scale is aligned with the definition of global citizenship education provided by UNESCO (2015) and Oxfam (2015). This study also tries to measure the level of global citizenship education in Malaysian students. Bitna (2017) stated that it was not easy to find research focused on this education in ASEAN countries. Most of the current research is conducted based on western cultures (Dill, 2013; Seo, 2016), and only a few studies carried out in Malaysia context (Maizura, 2010; Mahmood, 2014). Therefore, this study attempts to examine the perceptions of students by the level of knowledge, skills an attitude in global citizenship education based on the Malaysia context.

\section{METHOD}

This study used a quantitative approach and was conducted to get students' perceptions of knowledge, skills, and attitudes towards global citizenship. Data collected through a questionnaire administered to semester one diploma students at a public university. A total of 278 randomly selected students from a total population of 1000 students involved in this study. However, only 242 questionnaires returned and only 155 completed questionnaires analyzed. The 155 samples in this study comprised 131 females $(84.5 \%)$ and 24 male (15.5\%) students. 79 (51\%) from semester 1 students, $21(13.5 \%)$ from semester 3 and 55 (35.5\%) from semester 4 students. The selection of these diploma students as respondents made because they had just finished secondary schools, and their experiences in global education were still fresh in memory. They also came from various schools in Malaysia and were able to draw their perceptions on the global citizenship education they received in secondary school.

The questionnaire was modified and adapted from target elements 4.7 (UNESCO, 2017b). UNESCO and the International Association for the Evaluation of Educational Achievement (IEA) had established an official agreement to collaborate to measure Global Citizenship Education (GCED) and Education for Sustainable Development (ESD). This measurement consisted of seven elements with a 5-point Likert scale. The seven elements are human rights, sustainable development, climate change, peace and non-violence, global citizenship, gender equality and health and well-being. These elements measured based on the level of knowledge, skill and attitude of the students. The instrument presented in the English language. A pilot study was carried out to the other Diploma students that are not involved in this study. The instrument reliability, the Cronbach's alpha (.981) were adequate. The data collected were analyzed using the Statistical Package for Social Science (SPSS 20). The result of the descriptive analysis, correlations and regression are presented in the next session.

\section{FINDINGS AND DISCUSSION Findings}

The findings showed that knowledge, skills and attitudes aspects of all elements of citizenship education are at a moderate level. Table 1 showed that the level of knowledge and its' elements are the highest compared to the elements of attitudes and skills of global citizenship education. The security and prosperity elements showed the highest mean in knowledge, followed by skills and attitudes.

Table 1. Knowledge, Skills and Attitudes Stage on the Elementary Education Element of Education

\begin{tabular}{|c|c|c|c|c|c|c|}
\hline \multirow{2}{*}{$\begin{array}{l}\text { The element of the education of global } \\
\text { citizenship }\end{array}$} & \multicolumn{2}{|c|}{ Knowledge } & \multicolumn{2}{|l|}{ Skill } & \multicolumn{2}{|c|}{ Attitude } \\
\hline & Mean & SD & Mean & SD & Mean & SD \\
\hline Human rights & 3.63 & .636 & 3.36 & .654 & 3.50 & .678 \\
\hline Sustainable Development & 3.47 & .609 & 3.28 & .655 & 3.32 & .698 \\
\hline Security \& Prosperity & 3.95 & .816 & 3.73 & .871 & 3.67 & .861 \\
\hline Global Citizenship & 3.40 & .709 & 3.26 & .702 & 3.21 & .709 \\
\hline Gender Equality & 3.64 & .851 & 3.48 & .892 & 3.51 & .902 \\
\hline Health \& Wellness & 3.79 & .737 & 3.63 & .760 & 3.66 & .797 \\
\hline Overall & 3.65 & .541 & 3.46 & .577 & 3.49 & .613 \\
\hline
\end{tabular}


Table 2 showed that all the elements of global citizenship education show a significant correlation between knowledge towards the skills and attitudes of global citizenship. All the correlations shown are also high and positive between $\mathrm{r}=.625$ and $\mathrm{r}=.893$.

Table 3 showed the result of multiple linear regression analysis. Multiple regression was carried out to investigate whether Attitude and Skill could significantly predict the students' knowledge. The result of the regression indicated that the model explained $61.6 \%$ of the variance and that the model was a significant predictor of students' knowledge, F $(2,152)=121.7, \mathrm{p}=$ .000 . While Skill contributed significantly to the model $(\mathrm{B}=.756, \mathrm{p}<.05)$, Attitude did not $(\mathrm{B}=$ $.050, \mathrm{p}=1.665)$. Thus, the final predictive model was,

Knowledge $=.784+(.756 *$ Skill $)+(.050 *$ Attitude $)$

\section{Discussion}

The findings showed that the level of knowledge, skills, and attitudes of students towards the element of citizenship is still at a moderate level. All the elements consisted of human rights, sustainable development, security and prosperity, global citizenship, gender equality, health and wellness scored higher in knowledge compared to skill and attitude. The findings showed that students are having a positive experience in the global education of the citizenship they receive at school. The gained more knowledge directly or indirectly in global education taught at school and affected the students' skills and attitudes towards global citizenship education. This finding is in line with a study conducted in Poland by Leek (2016). In Poland, global citizenship education had been implemented in student life as early as six years old and it continues until they reached 18 years old. It stated that global citizenship education in Poland is carried out indirectly through a variety of social activities. Their learning objectives embed in various patriotic social events in Poland, continental Europe and globally. They were aimed to produce global citizens with local identity. Therefore, the students are encouraged to see the world's problem as their country's problem, as the two are interconnected to each other (Leek, 2016). Cheng (2003) describes this phenomenon using tree theory, where values and local culture are taught by absorbing global resources. As a result, the locals will have their global perceptions and act well both locally and internationally. Thus, it showed that global citizenship education should not only be taught

Table 2. The Correlation between Knowledge with the Skills and the Attitude of Global Citizenship

\begin{tabular}{llc}
\hline Knowledge & Skill & Attitude \\
\hline Global Citizenship & $.893^{* *}$ & $.814^{* *}$ \\
Human rights & $.735^{* *}$ & $.688^{* *}$ \\
Sustainable Development & $.837^{* *}$ & $.777^{* *}$ \\
Security \& Prosperity & $.761^{* *}$ & $.659^{* *}$ \\
Global Citizenship & $.855^{* *}$ & $.798^{* *}$ \\
Gender Equality & $.873^{* *}$ & $.824^{* *}$ \\
Health \& Wellness & $.787^{* *}$ & $.625^{* *}$ \\
\hline
\end{tabular}

**. Correlation is significant at the .01 level (2-tailed).

Table 3. Regression Analysis Summary for Skill and Attitude in Predicting Knowledge

\begin{tabular}{lccccc}
\hline Variable & $\mathbf{B}$ & $\mathbf{9 5 \%} \mathbf{C I}$ & $\boldsymbol{\beta}$ & $\mathbf{t}$ & $\mathbf{p}$ \\
\hline (Constant) & .784 & {$[.430,1.138]$} & & 4.378 & .000 \\
Skill & .756 & {$[.512,1.00]$} & .737 & 6.120 & .000 \\
Attitude & .050 & {$[-.179, .280]$} & .052 & .434 & .665 \\
\hline
\end{tabular}

Note: $\mathrm{R}^{2}=.616$, Adjusted $\mathrm{R}^{2}=.611(\mathrm{~N}=155, \mathrm{p}<.05), \mathrm{CI}=$ confidence interval for $\mathrm{B}$. 
formally in schools, but students can also get this education informally from reading the internet, mass media as well as from community behaviour.

The knowledge in global citizenship education that introduced in every subject has given a good impact on the students. Although the result showed that students' knowledge, skills and attitude are still at a moderate level, but it is a good benchmark for the effectiveness of an introduction of global citizenship education in school. The study of Sklad, Park \& Oomen (2016) stated that the introduction of this education in their University curriculum helps them to gain a global perspective, global competence, a sense of social responsibility, and intercultural communication competencies. Moreover, their findings found that students with early exposure to this subject had a more openminded attitude to cultural differences, a better understanding of other societies and other social perspectives, and it also increased their ability to asses global justice problems. They also had a more profound appreciation of the interactions between the local and global levels of social practices. Knowledge, skills and behaviour required an appropriate social environment (Stapa, Ismail, \& Yusuf, 2012). According to Ibn Khaldun "a good environment is necessary to produce good morals and good morals are to be born in oneself based on observations of environmental factors that may affect the habits of human life" (Stapa, et. al., 2012, p.157).

The findings also showed that there is a positive and significant relationship between knowledge, skills, and attitudes. This result showed that the introductions of global education elements in various subjects had succeeded to equip students with knowledge, skills and attitude that based on and instil respect for human rights, social justice, diversity, gender equality, environmental sustainability and empowers learners to be responsible global citizens. This finding is in line with the study of Mahat, Che Ngah, \& Idrus (2013), where they found out that students have a high level of knowledge and attitude towards the awareness of sustainable development education. However, they are not capable of translating the knowledge into behaviour and commitment towards environmental sustainability. A study by Kumari, Sharma \& Joythi (2018) also showed that students perceived positively towards global citizenship education and came up with the view that a culture of peace will be achieved when citizens of the world understand the global problems and have the skills to resolve conflicts peacefully. Some of the students also have a comprehensive and optimistic understanding of this subject, such as Global citizenship is a freedom of speech, religion, thought, coming from different cultures and fighting for justice, and learning as much as you can about other countries. Mahat, et. al. (2013) suggested that the teaching of love to the environment through activities or programs can be translated into positive behaviour towards the environment. To make this informal activity formal, it is proposed that the Ministry of Education (Malaysia) emulate Oxfam (2015), which provides guidelines for schools and teachers to conduct activities for global citizenship education or adopting guidelines provided by UNESCO (2015).

The multiple regression results showed that attitude and skill are a predictor of the students' knowledge. This analysis revealed an interesting finding where skill is contributed significantly to the model but not the attitude. This result is in line with the suggestion of The Partnership for $21^{\text {st }}$ Century Skills Framework (P21) that listed learning and thinking skills (for example, criticalthinking and problem-solving), ICT literacy and life skills (for example leadership) are must-have skills in global education in the $21^{\text {st }}$ century. A study by Widarto, Pardjono, \& Widodo (2012) stated that the development of soft skills and hard skills are important in $21^{\text {st }}$ Century. Zierer (2017) had listed three core skills needed in global skills, which are critical thinking, self-leadership and intercultural communication. Oxfam (2015) also emphasized that developing skills in both critical and creative thinking, reasoning, and communication can inspire learners and raise their motivation. UNESCO (2015) also emphasis that Global Citizenship Education aims to enable learners to develop and apply critical skills for civic literacy, which are in culture, language, religion, gender, critical thinking, decision making, problem-solving, negotiation, peace building and personal and social responsibility. The skills also included the ability to filter the abundance of information received through social media, internet or various resources. 
In this era of globalization, pieces of information from various countries can be accessed easily through the increase of technologies advancement. The advancement of communication technologies creates a borderless world and widely used as a major source of information worldwide. According to Kim, Kavanaugh \& Hult (2011), technologies play a significant role in the information exchange and as a source of dissemination in global citizenship education as it can be accessed quickly and adopted by most communities around the world. The society is free to express their opinions through various social mediums. It makes the behaviour of the community more observable through multiple applications used by internet users. However, all this technological advancement has positive and negative effects. According to Cheng (2003), the positive effects are knowledge sharing, skills, understanding promotion, collaboration, harmony and cultural acceptance across countries. Thus, if the information not contained, it will negatively affect the life of the worldwide citizen. Adesina (2012) highlighted the negative impacts of technologies in Nigeria as its' influence and change people's moral perspective and ethical values, and it exposes youth to negative cultures. These will influence the belief and principles in the everyday life of developing country communities, thus affect the communities in other countries (Murdiono, 2014). His study stated that religious, humanitarian, unity, citizenship and justice are fundamental values in international socializing. Humanitarian awareness, sustainable development, global citizenship, peace, health and well-being need to be disseminated in the world community as an effort to make the earth a better and safer place for the next generations.

In Malaysia, the subjects of Civics and Citizenship Education were introduced in 2005, beginning in Year 4 of elementary school and Form 1 of secondary school. It plays a significant role in the Malaysia education system to unite different cultures and beliefs of the community after Malaysia's independence in 1957. The study of Rizal's (2002) found that understanding and appreciation of citizenship values were still loose and at an average level, despite the 13 years of the education process. This study is similar to the study by Hasnah,
Mahzan, \& Razaq (2013) that showed the level of student citizenship knowledge in Malaysia is still at a moderate level. Civic education skills will enable students to act effectively and accountable to local communities, states and standards of globalization to preserve the peace of the world. It is including the development of self-motivation and necessary actions taken to defend the prosperity of the country and the world.

One of the programs included in the global civic education in Malaysia is the Sustainable School Program. This program tries to nurture student awareness about sustainable development and to implement the National Environment policy introduced in 2002. Since 2005, a competition of Environmental Education Sustainable School has been held aiming at shaping school environment based on environmental restoration and preservation through management, curriculum, cocurriculum, and migration. It establishes a practice in living harmoniously with the concept of sustainable development. The findings of Mahat, et. al. (2013) on student awareness in the context of environmental sustainability found that the level of knowledge and attitude of the students was high, but the level of behaviour and commitment was modest. Their findings showed that knowledge and attitude not translated by the students through their behaviour and commitment. They suggested that the role of teachers and parents should be improved.

The implementation of this subject in the curriculum may face certain constraints and contextual challenges. UNESCO (2015) highlighted several challenges that faced by educators in implementing this subject such as lack of books and other resources, overcrowded classroom, teachers with limited education training and no education training, the pressure to prepare students for national examinations and some of the content might have political, social or cultural sensitivities. The teaching and learning of this education are found to be ineffective due to the lack of interest and commitment among teachers (Chang, 2005). The findings from Maizura's (2010) on teacher readiness in teaching the content of Civic and Citizenship Education in Form 1 showed that the level of teacher readiness is at a moderate level. There is a significant difference between 
teachers who have received training and those who did not receive training in the content of the subjects. According to study by Mahmood (2014), several problems arise in teaching this subject even though teachers were given educate training, most of the teachers said that they received less support from their colleagues and administrator to teach this subject effectively, they also used traditional teaching approach, and their lack of knowledge and confidence to interpret and explain some of the themes in the issues had made them relied only to textbook provided.

The study by Buchanan, Burridge, \& Chodkiewicz (2018) found that to enhance global citizenship education in schools, teachers must adapt to global pedagogy and illustrating a clear framework. For example, Australia had introduced The Australian Global Education framework that stated clearly the fundamental assumptions and universal set of different values needed in global citizenship education. This framework will be able to form a holistic and critical pedagogy that will enhance student learning. A study by Cho (2016) found that although teachers used the same GCE terms, their intentions and understandings in the subject differ depending on their perspectives. Teachers are still lacking in showing effective responses, such as empathy, respect for diversity and behavioural aspects. Teachers tend to believe that the socio-emotional aspects of global citizenship education, which are empathy, caring for others, and mutual respect are the most critical. The study conducted should address the teachers with various experiences, backgrounds, and styles.

Although teachers are less focus on teaching this subject, the implementation of GCE at every level of education in Malaysia is essential. It will ensure that Malaysia students will get broader exposure to global issues. Therefore, through the new Standard Based Curriculum for Secondary Schools (KSSM), Malaysia had introduced elements of Civics and Citizenship Education in various subjects. The competence of citizenship values in Civic and Citizenship Education can be used to teach the elements of global citizenship in multiple subjects (Hasnah, et. al., 2013). Although these elements embedded in various subjects, a study by Hasnah, et. al. (2013) found that teachers are the primary concern in teaching this subject. One of the main issues is that teachers only using textbooks as teaching materials. Thus, it makes teaching and learning less effective. It happened because the subject of Civics and Citizenship Education is not included in the national examination. Therefore, teachers are less focused on the preparation of teaching aids. A study by Balakrishnan (2010) stated that this subject had always given less importance due to the constraints of other essential subjects in the national examination. This study is in line with a study by Sumardjoko (2018). He found that the main problems in teaching this subject in Indonesia are the suitability of materials, time allocation contains in the curriculum is not balanced, monotonous learning process, low students motivation and perception of the students that the subject is not important.

Overall, this study found that global citizenship education in Malaysia still at a moderate level due to various contributing factors discussed above. However, the need to implement this subject in school curriculum is essential to create a desirable global community. Through this subject every individual will feel responsible for showing an excellent example to the younger generation. Therefore, it will ensure that the nature of civilization, compassion, peace and harmony can be developed.

\section{CONCLUSION}

Global citizenship education is an important field in advancing a country. The findings in this study show that global citizenship education needs to be applied in elementary school until the university level. The implementation of this education in school curricula could help to build the fundamental values of global citizens in the students' life. This study also showed that the level of knowledge, skills, and attitudes of global citizenship education are related to each other. It showed that GCE is not just raising an international awareness but also values and attitude of the students, and their involvement in proactive action. The third finding showed that skills are the main predictor in the knowledge of global education.

The various conceptual frameworks of GCE in international education, multicultural education, global education, human rights 
education, peace education, or education for sustainable development (Rapoport, 2010; UNESCO, 2013) made it difficult to compare the level of global education in our country to the other countries. Therefore, this study proposed that all those who play a significant role in education should have the same understanding and meaning on GCE, as well as implementing them in the same way so that the goal is achieved. According to Kerr (1999), a model of citizenship education is sufficient to equip the community with effective citizenship education. The application of the model, which is consists of knowledge, values, attitudes, and skills, could ensure students to engage more effectively in the global world. Thus, the findings of this study could be used to enhance the awareness of GCE's interest in generating global citizens with better holistic values. Furthermore, it will improve the quality of education in Malaysia by giving students early exposure to current global issues. It also will educate the teachers in providing a comprehensive knowledge through teaching and learning across schools' curriculum directly or indirectly.

Overall, this study has shown that students' knowledge, skills, and attitudes toward global citizenship education are at a moderate level. However, this study cannot be generalized to all populations, and places as the respondents of this study are limited to a small number of students. A more in-depth study on global citizenship education should be enriched as studies in this area are still far-reaching in Malaysia. For further study, the study should be conducted on different populations and samples. The expansion of multidimensional samples is also proposed in the study to be carried out. Different perceptions in terms of understanding, beliefs, culture, and race among multiracial students, may occur. In addition, to increase the validity of the findings, it is proposed to supplement the questionnaire items.

\section{ACKNOWLEDGEMENT}

Acknowledgment is addressed to the Sultan Idris Education University that funded this study through the University Research Grant (2018-0223-107-01).

\section{REFERENCES}

Adesina, O. S. (2012). The negative impact of Globalization on Nigeria. International Journal of Humanities and Social Sciences, 2(15), 193-201. doi:10.5281/ zenodo.1410602.

De Andreotti, V. O. (2006). Soft versus critical global citizenship education. In S. McCloskey (ed.), Development Education in Policy and Practice (pp. 21-31). London: Palgrave Macmillan. doi:10.1057/9781137324665 2.

Balakrishnan, V. (2010). The development of moral education in Malaysia. Asia Pacific Journal of Educators and Education, 25, 89-101.

Buchanan, J., Burridge, N. \& Chodkiewicz, A. (2018). Maintaining global citizenship education in schools: A challenge for Australian educators and schools. Australian Journal of Teacher Education, 43(4), 51-67. doi:10.14221/ ajte.2018v43n4.

Bitna, J. (2017). Teachers' perception on global citizenship education in ASEAN countries. (Master Thesis, Seoul National University). Retrieved from https://snukr. academia.edu/.

Chang, L. H. (2005). Pendekatan pendidikan sivik dan kewarganegaraan dalam milenium baru masalah pendidikan, 28(1), 195-204.

Cheng, Y. C. (2003, February). Local knowledge and human development in the globalisation of education. Paper presented at International Conference on Globalisation and Challenges for Education: Focus on Equity and Equality, New Delhi, India.

Cho, H. S. (2016). The Gaps between values and practices of global citizenship education: a critical analysis of global citizenship education in South Korea (Doctoral Dissertations, University of 
Massachusetts Amherst). Retrieved from https://scholarworks.umass.edu/ dissertations $2 / 736$.

Cho, H. S. (2017). Issues and challenges of educators in implementing global citizenship education in South Korea. KEDI Journal of Educational Policy, 14(2), 21-39.

Dill, J. S. (2013). The longings and limits of global citizenship education: The moral pedagogy of schooling in a cosmopolitan age. New York, NY: Routledge. doi:10.10 80/00071005.2013.877621.

Davies, I. \& Pike, G. (2011). Global citizenship education: Challenges and possibilities. In Lewin, R. (Eds.) The handbook of practice and research in study abroad: Higher education and the quest for global citizenship (pp. 61-77). New York, NY: Routledge. doi:10.1111/j.14679647.2010.00680.x.

Ferreira, R. (2011). Development of an instrument to measure high school students' global awareness and attitudes: Looking through the lens of social sciences (Doctoral dissertation, Florida International University). Retrieved from: https://digitalcommons.fiu.edu/etd/373/. doi:10.25148/etd.FI11050306.

Friedman, J. (2000). Globalization, class, and culture in global systems. Journal of World System Research, 6(3), 636-656. doi:10.1177/0896920513497377.

Goren, H. \& Yemini, M. (2017). Global citizenship education redefined - A systematic review of empirical studies on global citizenship education. International Journal of Educational Research, 82(C), 170-183. doi:10.1016/j.ijer.2017.02.004.

Hasnah, S., Mahzan, M., \& Razaq, A. (2013). Penerapan kompetensi kewarganegaraan melalui pelaksanaan Pendidikan Sivik dan Kewarganegaraan (PSK) dalam kalangan guru Sekolah Menengah di Malaysia. Paper presented at Seminar Serantau,

\section{Universiti Kebangsaan Malaysia, Malaysia.}

Hunt, F. (2012). Global learning in primary schools in England: Practices and impact. London: Development Education Research Centre.

Hull, G. A. \& Stornaiuolo, A. (2014). Cosmopolitan literacies and social networks. Curriculum Inquiry, 44(1), 1544. doi:10.1111/curi.12035.

Keating,A.(2009). Nationalizingthepostnational: Reframing European citizenship for the civics curriculum in Ireland. Journal of Curriculum Studies, 41(2), 159-178. doi:10.1080/00220270802467475.

Kerr, D. (1999). Citizenship education: An international comparison. London: Qualifications and Curriculum Authority. Retrieved from https://edudoc.educa.ch/ static/xd/2003/59.pdf.

Kim, B. J., Kavanaugh, A. L., \& Hult, K. M. (2011). Civic engagement and internet use in local governance: Hierarchical linear models for understanding the role of local community groups. Administration \& Society, 43(7), 807-835. doi:10.1177/0095399711413873.

Kumari, S., Sharma, S., \& Joythi, J. (2018). Promoting global citizenship education with science teaching and analysing the way it is perceived by students at secondary level. PEOPLE: International Journal of Social Sciences, 3(3), 1483-1496. doi:10.20319/pijss.2018.33.14831496.

Leek, J. (2016). Global citizenship education in school curricula: A polish perspective. Journal of Social Studies Education Research, 7(2), 51-74.

Mahat, H., Che Ngah, M. S. Y., \& Idrus, S. (2013). Kesedaran pendidikan pembangunan lestari menerusi program sekolah lestari dalam kalangan pelajar. Geografi, 1(2), 46-60. 
Mahmood, H. (2014). Civics and citizenship education in Malaysia: The voice of micro policy enactors. (Doctoral Thesis, Cardiff University). Retrieved from http://orca. cf.ac.uk/id/eprint/69576.

Maizura, Y. (2010) Tahap kesediaan guru terhadap pengetahuan kandungan pedagogi pendidikan sivik dan kewarganegaraan tingkatan satu. (Master's Thesis, Universiti Putra Malaysia). Retrieved from http://psasir. upm.edu.my/id/eprint/11069/.

Morais, D. B. \& Ogden, A. C. (2011). Initial development and validation of the global citizenship scale. Journal of Studies in International Education, 15(5), 445-466. doi:10.1177/1028315310375308.

Murdiono, M. (2014). Pendidikan kewarganegaraan untuk membangun wawasan global warga negara muda. Cakrawala Pendidikan, 33(3), 349-357. doi:10.21831/cp. v3i3.2379.

Niens, U. O'Connor, U. \& Smith, A. (2013). Citizenship education in divided societies: teachers' perspectives in Northern Ireland. Citizenship Studies. doi:10.1080/1362102 5.2012.716214.

Oxfam. (1997). A curriculum for global citizenship. Oxford: Oxfam United Kingdom \& Ireland.

Oxfam. (2015). Education for global citizenship: A guide for school. Oxford: Oxfam Development Education.

Pavlov, I. P. (1910). The work of the digestive glands (Trans by W. H. Thompson). London: C. Griffin. doi:10.5962/bhl. title.3784.

Rapoport, A. (2010). We cannot teach what we don't know: Indiana teachers talk about global citizenship education. Education: Citizenship and Social Justice, 5(3), 179190. doi:10.1177/1746197910382256.
Rizal, U. (2002). Nilai-nilai kewarganegaraan di kalangan pelajar Sekolah Menengah Tinggi Kajang. (Master Thesis, Universiti Kebangsaan Malaysia).

Seo, H. (2016). A study on secondary school teachers' global citizenship type and perceptions of global citizenship education. (Master Thesis, Seoul National University). Retrieved from http://hdl. handle.net/.

Skirbekk, V., Potančoková, M., \& Stonawski, M. (2013). Measurement of global citizenship education (Technical Report, No. 2014/ $\mathrm{ED} / \mathrm{TLC} / \mathrm{GCE} / 01$ ). Retrieved from a study commissioned by UNESCO for the Technical Consultation on GCE in Seoul, Republic of Korea website: https:// unesdoc.unesco.org/.

Sklad, M. F., J. Park, E. \& Oomen, B. (2016). Going glocal:Aqualitative and quantitative analysis of global citizenship education at a Dutch liberal arts and sciences college. Higher Education, 72(3), 323-340. doi:10.1007/s10734-015-9959-6.

Stapa, Z, Ismail, A. M., \& Yusuf, N. (2012). Faktor persekitaran sosial dan hubungannya dengan pembentukan jati diri. Jurnal Hadhari, Special Edition (2012), 155-172.

Stevens, V. H. (2013). Students' perceptions on issues related to globalization at a four-year community college in Florida (Dissertation, University of South Florida). Retrieved from http://scholarcommons. usf.edu/.

Sumardjoko, B. (2018). Model of civic education learning based on the local wisdom for revitalizing values of Pancasila. Cakrawala Pendidikan, 37(2), 201-211. doi:10.21831/cp.v37i2.18037.

Thier, M. (2016) Maturing measurement: Validity and reliability trials of a measure of global citizenship for high school students. Retrieved from https://aefpweb. org/. 
Toh, S. H., Shaw, G., \& Padilla, D. (2017). Global citizenship education: A guide for policymakers. Seoul: Asia-Pacific Centre of Education for International Understanding (APCEIU).

UIS. (2014). Towards Indicators for a post2015 education framework. Montreal: UNESCO Institute for Statistics. Retrieved from http://www.uis.unesco.org/.

UNESCO. (2013). Global citizenship education: An emerging perspective (Outcome document of the technical consultation on global citizenship education). Retrieved from http://unesdoc.unesco.org/.

UNESCO (2014). Global citizenship education: Preparing learners for the challenges of the twenty-first century. Paris: UNESCO. Retrieved from http://unesdoc.unesco. org/.

UNESCO. (2015). Global citizenship education: Topics and learning objectives. Retrieved from https://unesdoc.unesco.org/.

UNESCO. (2017a). Measuring global citizenship education. A collection of practices and tools. Retrieved from Center for Universal Education at the Brookings Institution website: https://www.brookings.edu/.
UNESCO. (2017b). Measurement strategy for SDG Target 4.7 (Proposal by GAML Task Force 4.7). Retrieved from Global Alliance for Monitoring Learning website: http://uis.unesco.org/.

Widarto, W., Pardjono, P., \& Widodo, N. (2013). Pengembangan model pembelajaran soft skills dan hard skills untuk Siswa SMK. Cakrawala Pendidikan, 31(3), 409423. doi:10.21831/cp.v0i3.1139.

Wintersteiner, W., Grobbauer, H., Diendorfer, G, \& Reitmair-Juárez, S. (2015). Global Citizenship Education: Citizenship education for globalizing societies. Retrieved from http://www. demokratiezentrum.org/.

Zierer, T. (2017). The effects of different types of experience abroad in higher education on global skills. (Bachelor Thesis, The University of Twente). Retrieved from https://essay.utwente.n1/.

Zuriah, N. (2012). Kajian etnopedagogi pendidikan kewarganegaraan sebagai wahana pendidikan budaya dan karakter bangsa di Perguruan Tinggi Muhammadiyah Kota Malang. Jurnal Humanity, 8(1), 170-185. 